\title{
Gender and Instructional Materials as a Correlate of Grade 6 Learners' Mathematics Performance in Buffalo City, South Africa
}

\author{
K. O. Adu*, N. Duku \\ Faculty of Education, University of Fort Hare, East London 5200, South Africa \\ Received September 15, 2020; Revised January 11, 2021; Accepted January 20, 2021
}

\section{Cite This Paper in the following Citation Styles}

(a): [1] K. O. Adu, N. Duku, "Gender and Instructional Materials as a Correlate of Grade 6 Learners' Mathematics Performance in Buffalo City, South Africa," Universal Journal of Educational Research, Vol. 9, No. 3, pp. 413-422, 2021. DOI: 10.13189/ujer.2021.090301.

(b): K. O. Adu, N. Duku (2021). Gender and Instructional Materials as a Correlate of Grade 6 Learners' Mathematics Performance in Buffalo City, South Africa. Universal Journal of Educational Research, 9(3), 413-422. DOI: 10.13189/ujer.2021.090301.

Copyright $\bigcirc 2021$ by authors, all rights reserved. Authors agree that this article remains permanently open access under the terms of the Creative Commons Attribution License 4.0 International License

\begin{abstract}
Mathematics is the foundation for the economic and technological development of any nation. It has been asserted that Mathematics is expected to help in accelerating the socio-econo-techno progress of any society. The purpose of this paper is to find out the correlation between the utilization of instructional materials and Grade 6 learners' performance in Mathematics in Buffalo City. Despite the importance of Mathematics as the gateway to the world of science and technology, Mathematics is also regarded as the subject in which many learners underperform. The study adopted a correlational research design and a quantitative approach. The target population of this study was Grade 6 learners in the Buffalo City district. Stratified sampling was used to select 1225 Grade 6 learners. The findings showed that there is a significant relationship between the availability and utilization of instructional materials and Grade 6 learners' performance in Mathematics in Buffalo City $(\mathrm{r}=$ $0.999 ; p>0.05$ ). There is no significant difference between gender and Grade 6 learners' Mathematics performance at Buffalo City $(\mathrm{t}=-.217, \mathrm{df}=1218, \mathrm{p}>0.05)$. The mean difference between male learners $(\overline{\mathrm{x}}=12.820, \mathrm{SD}=3.969)$ and female learners $(\overline{\mathrm{x}}=12.872, \mathrm{SD}=4.098)$ was negligible. It was observed that where materials are available, the management, selection, and effective use are lacking. It is recommended that teachers should not only be encouraged on the use of instructional materials but also be capacitated and guided on the effective use, management, improvisation, and selection of relevant and appropriate
\end{abstract}

materials.

Keywords Educators, Learners, Instructional Materials, Gender, Mathematics, Performance

\section{Introduction}

Mathematics is a science subject that is taught at any level of education. The inadequacy of this subject at the tertiary level is a result of the weak foundation at the primary school level. Therefore, the level of primary school is very important in any nation's education system (21). Mathematics can be interpreted broadly as something a person does to solve real-life problems. It can also be compared to a strategy for addressing issues, such as in science and geography. To fast-track the socio-economic and technological growth of any society, there is a need for a solid foundation in Mathematics [11]. [21] opines that a strong foundation of Mathematics at the primary school level might greatly contribute to counteracting and inadequacy of this subject at the tertiary level.

Despite the emphasis placed on Mathematics, many learners still find it difficult to cope with the study of Mathematics in schools. Thus, if the set objectives for Mathematics are to be achieved, concerted efforts should be made to provide adequate instructional 
materials to learners and to encourage the effective use thereof in schools. Every child follows his/her unique way to learn and process information, and the use of instructional materials enables teachers to disseminate concepts and ideas with ease, as they appeal to the senses of the learner at a particular period, and as such facilitating teaching and learning [29]. Despite the emphasis placed on instructional materials in the teaching and learning of Mathematics, many learners are still underperforming. This may be as a result of inadequate instructional materials, or the underutilization thereof by teachers.

[30] describes instructional materials, from basic chalkboard drawing to sophisticated overhead transparencies and computers, covering a wide variety of visual and audio media. In the primary school curriculum, instructional materials, which are educational inputs, are of critical importance for teaching any subject.

[42] and [30] believe the use of instructional materials and positive learning styles would make discovered facts securely glued to the learners' minds. Instructional materials can be improvised [41]. [27] noticed that extemporization requests experience, inventiveness, interest, and steadiness concerning educators. Such abilities are just acknowledged through very much arranged preparation programmes on improvisation. The researchers believe that there are some instructional materials that the teachers can provide within the learning environment for teaching Mathematics, such as bottle-tops, counters, matches sticks, charts, etc.

Instructional materials like textbooks, charts, graphs, workbooks, and pictures are important artifacts used in the teaching of Mathematics. "Instructional materials should arouse students' interest in learning Mathematics, help students to study Mathematics actively, develop students' potential in creativity through the process of learning basic knowledge, improve students' mathematical thinking when trying to understand the essence of mathematical knowledge, and raise students' awareness to apply mathematical knowledge in their everyday lives" [23]. Instructional materials are an integral part of teachers' daily activities, and the selection of appropriate curriculum materials will eventually lead to effective use of pedagogy and assist in discharging the subject matter to learners. Teachers play a pivotal role in translating the use and implementation of instructional materials (textbook and other written resources) throughout the year while aiming to achieve the desired learning outcomes [4].

Written curriculum materials such as textbooks, worksheets, charts, graphs, calculators, markers, and postcards are available for use with the guidance and assistance of the teachers. In addition to these instructional materials, computer software and geoboards also make an immense contribution to better performance of Mathematics across different levels of education [5]. Of all of the written curriculum materials mentioned above, textbooks are most widely used since textbooks are directly linked to the teaching and learning of any subject [4]. Mathematics textbooks are very important because most teachers depend on them for making decisions on what to teach, how to teach, and what tasks and classwork to give to learners at different stages of classroom teaching. An inference that can be made is that Mathematics textbooks can contribute to solving problems experienced by both teachers and learners. In general, instructional materials such as textbooks, written texts, computer software, digitals, audios, videos, or hands-on materials, such as manipulatives and geoboards are built into mathematical and instructional intentions and possibilities for school Mathematics [4].

For students to learn mathematical content, instructional materials are essential, as teachers often rely heavily on instructional materials and learners' readiness for many decisions, such as what assignments to give to learners, how and what to teach, and what exercises to assign to their learners. With learners being able to see, touch, smell, or even taste, learning is made more meaningful. This aligns with the Chinese proverb which states that; "what I see-I remember, what I hearI forget and what I do I understand". [35] saw instructional materials as information carriers designed specifically to fulfil objectives in teaching and learning situations. [34] views instructional materials as:

All the physical (Synthetic and material that are real and spontaneous) resources are meant to be used by the facilitator in the process of teaching and learning. These materials may be used singly or in combination. In some cases, they could be used informally or formally.

This shows educators shift the strategies for using instructional materials during guidance to impact changes in the conduct of the students. The suitable utilization of instructional materials goes far in improving educating and picking up, exciting interest, and upgrading understudies' emotional reactions. [24] sees that:

Learning experiences that stimulate or appeal to limited senses of receiving information would not be enough for the teacher to convey meaningful information to stimulate the learner for the development of cognitive, affective, and psychomotor skills or competencies reminiscent of learning.

This requires the utilization of an assortment of instructional materials during the educating learning measure. The adequacy of learning relies upon what students take a gander at and tune in to which impacts their conduct. The association and utilization of instructional materials are significant for most extreme educating and learning just as helpful in the maintenance of scholarly ideas. [42] succinctly describe the use of instructional materials as what would make discovered facts glued firmly to the memory of the learners. 
[33] also added that a well-planned and creative use of visual aids in the delivery of a lesson could do much to banish indifference, supplement the inadequacy of books as well as arouse learners' interests by giving them something practicalto see, do, and at the same time helping to train them to think abstractly. [39] expounded on this statement when stating that the selection of instructional materials that are related to the basic contents of a lesson, helps in improving learners' understanding of such a lesson. It also makes the lesson attractive and as such motivates learners to learn. Savoury encouraged the use of pictures, which he states, is fulfilling an important role to help learners in grounding their thoughts and feelings. Savoury further notes that pictures that work more effectively than imagined objects, are to be used as alternatives to real objects where it is impossible to show learners the real objects. [24] affirms this view when asserting that the learning of real information in a shorter time as opposed to verbalisation, is more effective with the availability of instructional materials. [24] concedes that instructional materials especially pictures, can arouse and help further study; and help learners to become more active and interested in the topic being taught when available and used appropriately. [4] concedes that the ability of teachers to select proper instructional materials and the appropriate use thereof when teaching Mathematics has a lot of influence in activating the thinking process and learners' performance in Mathematics.

[25] recognizes that extensive use of educational materials helps provide learners with an encouraging atmosphere for learning mathematics as educational materials to make teaching and learning more effective. [17] affirm this view when stating that in the creation of any curriculum, instructional materials are required ingredients. Grade 6 learner performance in Mathematics continues to be a great source of concern in South Africa and the Eastern Cape Province where this study was conducted. Results from the Grade 6 Annual National Assessment tests in 2016 show an overall pass rate of $43 \%$ at the national level, and a mere $23 \%$ for Mathematics for Eastern Cape Grade 6 learners. It is against this background that the use of instructional materials as correlates for Grade 6 learners' Mathematics performance is explored.

\section{Objective of the paper}

To examine gender and instructional materials as a correlate of Grade 6 learners' Mathematics performance in Buffalo City.

\section{Hypotheses}

1. There is no significant relationship between availability and utilization of instructional materials on Grade 6 learners' performance in Mathematics.

2. There is no significant difference between male and female Grade 6 learners' performance in Mathematics.

\section{Kolb's Experiential Learning Theory}

This paper is anchored in Kolb's experiential learning theory. According to Kolb, experiential learning calls for strengths such as self-initiative and self-assessment. To be timely, experiential learning should use the wheel of full learning, from setting targets to testing and observing, evaluating, and finally acting. This complete process allows students to learn new skills in many subjects more particularly Mathematics, new attitudes, and new ways of thinking. Kolb's experiential theory, which involves four-stages of learning, "do, observe, think and plan", helps students to participate actively in learning [9].

Among the different models of learning style, Kolb's Experiential Learning Model (ELM) has been commonly used and updated to reflect the different educational contexts. Kolb proposes a hypothetical, four-stage learning cycle. Based on this model, individuals may show a preference for all the stages or may cope better with one particular stage. [31] concedes that learning is viewed as a continuous, interactive process in all these stages.

The four stages of the ELM are described as:

- Concrete experience (CE; experiencing) that promotes experiential learning

Abstract conceptualization (AC; reasoning) in which conceptual and analytical thinking is preferred to attain understanding;

- Active experimentation (AE; doing) involving active learning through trial and error; and

- Reflective observation (RO; reflecting) where the task and possible solutions are given thorough consideration before there is any attempt at action.

To understand the importance of instructional materials concerning the teaching and learning of Mathematics, it is important to briefly explain Kolb's learning theory. With its prime focus on learning, this theory is underpinned by the following basic tenets: concrete experience (experimenting); active implementation (doing); abstract conceptualization (thinking); and reflective observation. In line with Kolb's reasoning, the use of concrete instructional materials provides learners with hands-on opportunities to explore and actively engage in the study of Mathematics. The manipulation of concrete materials provides learners with opportunities to experiment and learn through trial and error and as such taking control of their learning. Moreover, with every child having its unique way of learning and processing information, instructional materials may enable learners to learn by doing, which is congruent with Kolb's principle of "active implementation". The use of instructional materials activates learners' abstract thinking and their interests by giving them something practical to see (observe); touch (learn by doing) and reflect on the connections of the 
mathematical problems they have seen and the correctness of the mathematical solutions provided to these problems (reflective observation).

\section{Literature Review}

\section{Instructional Materials and Mathematics Performance}

During education, instructional materials are described as concrete or physical items that provide sound, visual, or both to the sense organs [7]. [15] places that instructing and learning assets in the Mathematics homeroom are solid materials that can go from concrete to semi-concrete to extract materials. The creator surrenders that the control of these assets and resultant encounters gives students chances to make associations. Given these definitions, instructional materials involve various classifications that are comprehensive of visual materials for perusing and non-understanding materials, and general media materials including electrically worked and none electrically worked materials. [5] clarified instructional materials as assets or showing materials, which an educator uses throughout introducing an exercise to make the substance of the exercise reasonable to the student. They are of the view that one of the standards of Mathematics training is that the instructional materials to be utilized for the educating of students ought to be a copy of what is acquired in the students' condition

Teachers are expected to be familiar with the use of these critical resources to guide their classroom instructions and daily activities [43]. This includes the use of different instructional resources during the process of teaching. However, learning success depends on what the learners are looking at and listening to [20]. Organizing and using educational materials is essential for optimal learning and teaching as well as helping to maintain learned concepts. [20] notes that a systematic way of planning and designing instruction will make the learners learn more effectively, and that, the model for designing instructional materials should include; (a) instruction outcomes should be identified; (b) instruction should be developed, and (c) for instruction to be effective it should be evaluated. It is however observed that inadequate teaching experience, pedagogy, and andragogy make the adaptation of perfect classroom settings and the use of activities difficult. Thus, for the effective teaching of learners and the realization of learning objectives, there is a need for the proper use and mediation of instructional materials.

According to [37], the use of instructional materials at the primary level has become an accepted fact in the world. However, what has not been accepted is the "Modus Operandi" of using and management of instructional materials within the classroom. This implies that teachers differ in their mode of implementation and management of instructional materials in primary schools which has been identified as one of the challenges associated with teaching and learning. Ideally, no effective education programme can exist without equipment, facilities, and materials.

The teaching and learning of mathematics vary from one continent to another, and thus the use of educational materials to teach and learn mathematics is briefly examined from various perspectives. In Finland, the textbook is a commonly used instructional material for the effective teaching of Mathematics and Science. However, teachers do make use of supplementary instructional materials during teaching and assessment of learners, including manipulatives. Finnish education officers evaluate these materials before approval is given and prescribed a widely used textbook series for Grade 4 and 8 . In Australia, individual schools are responsible for selecting Mathematics and Science textbooks. To achieve good standards stated in the curriculum, the textbooks chosen by the school should adequately cover the contents of the subject. A report on the Teaching Mathematics and Science in Australia showed that Australian students and teachers of secondary schools were relatively well equipped with science laboratories, and reference instructional materials [10]. Due to the generalist nature of primary education in Australia, most primary schools did not have enough instructional materials [44].

In Australian colleges, calculators are widely used in mathematics. The Australian National Report on TIMSS 2011, Mathematics indicated that $95 \%$ of 4th-grade teachers enabled the use of classroom calculators primarily to check responses, solve complex problems and explore numerical concepts [28]. Similarly, at the eighth-grade level, 99 percent of Australian teachers allowed calculators to be used, mostly for routine computations, checking responses, and solving a complex problem. Computers are widely available in Australian schools, with approximately two-thirds of fourth-grade students and nearly 90 percent of eighth-grade students attending schools where there was at least one computer for every 1 to 2 students [44]. How computers are used varies from classroom to classroom. In addition to computers in classrooms, digital technologies have revolutionized distance education programs, such as Australia's Schools of the Air, which serves students in remote and isolated communities. Where the radio was utilized formerly (hence "School of the Air"), broadband satellite networks now allow Web conferencing and similar interactive technologies [28].

In Canada, the ministry of education in each jurisdiction evaluates, approves, and recommends instructional materials such as textbooks and equipment for teacher and student use. Canadian schools have manipulatives and resources in various forms like audio, video, digital, print, and hands-on-materials. In the United Kingdom, the catalogue of useful visual aids to help with the teaching of learners in public primary schools include 
visual aids such as pictures, postcards, diagrams, maps, films, strips, models, and the identification of materials that are suitable for the content of the subject to enhance a better understanding and make learners more active [39]. In their analysis focusing on 57 schools in England and Wales [14], they concluded that those learning institutions with comprehensive learning and teaching facilities, a favourable student-teacher ratio, a commendable workload, and good incentives and rewards for teachers perform better than those institutions that do not provide the same. In Nigeria, schools should be adequately and universally equipped with instructional materials such as suitable textbooks, qualified teachers, and equipped libraries to promote sound and effective teaching to achieve a just and equitable society, as described in the Nigerian National Education Policy [18]. In Tanzania, visual tools such as pictures, diagrams, projectors, teachers themselves, charts, real objects, books, newspapers, magazines, brochures, handouts, clock faces, simple abacus, coloured objects, marionettes, models, chalkboards, audio resources such as tape recordings, radios, CDs and dramatization are instrumental to the development of the child's mental and cognitive ability.

The instructional material normally utilized in South Africa are course readings that are intended to supplement the instructor's exertion in the conveyance of guidance and fill in as a manual to supplement what they realize in school. As indicated by the [46] report, course books are especially applicable to improving the presentation of the students' in Mathematics. Arithmetic reading material, similar to all course books, is needed to be following the subject educational plan. The subject educational plan contains the instructive substance on offer for each subject for a school year and fills in as the premise of the work routine structure [13]. It is in this feeling [4] sees course readings as hotspots for critical thinking, works out, reference books, and as an educator in themselves.

[25] Recognizes that the systematic use of educational resources helps to provide learners with an atmosphere for learning Mathematics as the use thereof makes teaching and learning more effective. [17] affirm this view when stating that in the creation of any curriculum, certain instructional materials are essential ingredients. These opinions advocate for the use during the teaching-learning period of varied instructional materials. Inferences that can be drawn are that learning efficacy depends on what students experience, touch, and listen to, reinforcing the value of the organization and use of instructional resources to optimize teaching and learning for the retention of learned concepts.

Despite the importance of educational materials, [36] and [16] found that if the students are interested in the topic and the teacher has a strong mastery of the subject matter, the inadequacy of instructional materials is not inherently significant. In support of this view, [9] argues that it is most important to involve learners in classroom activities as it makes teaching focused on learners. The researchers concur with [16]'s sentiment, who observed and experienced that whenever a teacher possesses the mastery of the subject matter and the use of learner-centered methods, such lessons are very lively and learners' level of retention is very high.

[4] emphasized the role that the environment plays in promoting the use and availability of instructional materials. The type of environment will determine the use of ICT equipment in schools. Some schools in Pretoria and Johannesburg in South Africa are enjoying modern ICT facilities while other areas are not [6]. An inference that can be made is that schools in remote rural areas without access to electricity are vulnerable concerning the use of electronic gadgets. Many schools in urban areas without adequate security are also vulnerable to vandalism, burglaries, and theft, which are resulting in major stumbling blocks concerning the use of instructional materials.

[27] states that it is possible to use extemporized instructional materials as training gadgets with which understudies can assemble accuracy, understanding, and skill. As [21] states, spontaneous instructional materials include the delivery and use of elective assets planned to encourage guidance. [19] On the side of this definition, it is claimed that impulsive materials involve the identification and transmission of essential teaching components for teaching and learning measures in the absence or deficiency of standard teaching and learning materials for the substantial recognition of the stated instructive goals and objectives [27] had previously noted that the approach of using extemporized materials in homeroom mathematics helped to present new skills in the best possible way, create understanding just as indicating students the fitting method of getting things done. [33] concludes that the non-use of instructional materials, lack of funds to acquire some of the materials that cannot be improvised, lack of adequate room facilities for storage and security facilities, inadequate regular electricity supply to sustain specific audio-visual resources that require specific room temperature are major hindrances to the use of instructional materials. Lack of adequately qualified subject specialists in the discipline (Mathematics) can lead to poor performance in the subject. [33] highlights some other factors that infringe on the appropriate use of instructional materials such as inadequate room facilities and budgets, poor planning, poor communication, unfamiliarity with audio-visual materials, and methods of teaching. The paper does not only encourage the effective use of instructional materials in South African schools but also eliminates the challenges that hinder the effective use of instructional materials.

\section{Gender and Mathematics Performance}

The components recognized in adding to the gender stereotyping issue in Mathematics Education in the created nations stay legitimate for Africa. Some different 
components are conspicuous when we are talking about Mathematics Education by and large. These incorporate among other; negative socio-social mentalities, family unit assignments at home, sexual orientation one-sided educational plan, poor instructive materials, absence of school offices (quarters), absence of sponsorship, unmotivated and unfit science instructors, absence of good and monetary parental help, absence of self-assurance among the young ladies, lacklustre showing in tests, and so on.

As indicated by the UNESCO Institute for Statistics report distributed in September 2010, the most minimal education rates were seen in sub-Saharan Africa, where the grown-up proficiency rate for guys is 71.6 and $53.6 \%$ for females, and in Northern Africa, it is separately 76.7 and $58.1 \%$. It ought to be featured that the greater part of the grown-up populace is as yet ignorant in the ten after nations: Gambia (55\%), Senegal (58 \%), Benin (59\%), Sierra Leone (60\%), Guinea (62\%), Ethiopia (64\%), Chad (67\%), Burkina Faso (71\%), Niger (71\%), and Mali (74\%). The net enrolment proportion in the grade young populace in sub-Saharan Africa nations is around $52.3 \%$ young ladies (and $60.7 \%$ young men), aside from in not many nations where practically all young ladies of elementary school age are selected at schools. In any case, there is a generous drop out among young ladies at the optional school level; it is expected to socio-social (early marriage), monetary reasons, institutional boundaries, and lacklustre showing of young ladies.

The Trends in Mathematics and Science Study [28] 2011 announced that somewhere in the range of 68 and $90 \%$ of African understudies in Grade 8 neglected to arrive at the low benchmark in Mathematics [45]. Besides, tragically, no critical advancement was enrolled in TIMSS 2011. It is a pity that Africa so inadequately spoke to in such a significant worldwide evaluation of the arithmetic and science information on the sixth grade understudied

As at the primary school level and in advanced education, no particular sexual orientation contrasts have been found in various investigations concerning Mathematics evaluations and sex disparity in admittance to advanced education [31] The biggest college in Mexico detailed in 2009 [38] that the level of female understudies was bigger than that of male understudies and that graduation rates supported ladies (56\% of ladies who graduated against $50 \%$ of men). Notwithstanding, there is as yet a serious under-portrayal of ladies in science. Just $38 \%$ of ladies join up with science programs, and $43 \%$ of all understudies who move on from these projects are ladies. The sex hole is more noteworthy when considering admittance to post-graduate training. In 2008, just $30 \%$ of understudies in postgraduate projects were ladies, even though in programmes identified with Mathematics Education female understudies involved $45 \%$.

In an examination including college professors, it was discovered that they considered male understudies more capable in arithmetic than females. They communicated similar convictions as those found among instructors in primary school about ladies being effective in arithmetic due to their exertion and control. Perception of classes recognized a more latent disposition of female understudies and an inclination of male understudies to be more participative. Even though outcomes show that, by and large, female understudies are more perseverant in their examinations, it appears to be that they despise everything to think about science as a male space, excessively serious for ladies and that educators' convictions will, in general, fortify this origination [25].

\section{Methodology}

The methodology of research is the task of selecting, reflecting, assessing, and explaining how a specific research study is intended by the researcher.

\section{Research Approach}

This study adopted a quantitative approach. The purpose of using this approach for this study is because it can predict human behavior or predict likely outcomes (identify relationships among variables). This approach is relevant to this study which is particularly aimed at exploring instructional materials as a correlate of Grade 6 Mathematics performance.

\section{Research Design}

A correlational research design was adopted by the researchers. A design for correlational research is a type of non-experimental quantitative design. The correlational design was therefore the most useful and acceptable research design for this research on the topic because of the high levels of uncertainty and ignorance; the paucity of existing research and literature on the research topic; and since this type of research is usually flexible without a formal structure.

\section{Population, Sample, and sampling techniques}

The target population for this study was Grade 6 learners in the Buffalo City district. Stratified sampling was used to select 1225 participants which were all Grade 6 learners.

\section{Data Collection Instrument}

\section{Availability and Utilization of Instructional Materials Inventory (AUIMI)}

Availability and Utilization of Instructional Materials Inventory (AUIMI) have two sections; section A and B. Section A consists of biodata information; which are, 
Name, School, and Gender. The biodata information is necessary especially the gender of the participants to know if it influences performance in Mathematics. Section $\mathrm{B}$ has fifteen (15) items with the following response scales; $\mathbf{A}=$ Available, $\mathbf{N A}=$ Not Available, if available, $\mathbf{U}=$ Use, NU = Not Use. The instructional materials used in this research are; hand-on-material, graphs, pictures(motion), diagram, maps, model objects, photographs, chalkboard, textbooks, and exhibits

\section{Validity and Reliability of AUIMI}

Different dimensions of validity and reliability comprising construct validity; content and concurrent validity were adopted to ascertain the accuracy, meaningfulness, and credibility of the instrument. The research instrument was first given to the experts in the field of Mathematics Education and the researcher's supervisor who assisted with the phrasing and selection of questions. The instrument was also pilot tested to increase the instrument's validity. The reliability was ensured by pilot testing the instrument, using similar samples, and calculating Cronbach's alpha. Since a co-efficient value of 0.89 was obtained, the level of consistency was high and the questionnaire was regarded as valid.

\section{Mathematics Achievement Test (MAT)}

This is a self-developed instrument. It is a multiple-choice objective test made up of 25 items from Grade 6 Mathematics from the content of Curriculum Assessment and Policy Statement (CAPS). The researcher and the supervisor preferred this (MAT) to obtain the learners' results from the school, which may be subjective. Each item has one correct option (key) and four distractors, i.e. options A, B, C, and D. The content area covers some topics in Mathematics. The scoring of the MAT was done on a dichotomous basis. The correct response earned one mark, while an incorrect response earned zero. This self-developed instrument has questions such as "What is the place value of the underlined digit in $4 \underline{5} 678921$ ? (A) 10000000 (B) 1000000 (C) 100000 (D) 100000 000"; "Which number is represented by $(50 \mathrm{x}$ $100000)+(3 \times 100000)+(900)+(7$ tens $)+9$ ? (A) 53 979 (B) 530979 (C) 5300979 (D) 503 979". The options provided to each of the 25 items consist of one correct option.

\section{Validity and Reliability of Mathematics Achievement Test (MAT)}

The MAT of 25 items was administered to 35 learners from another site to measure its reliability coefficient using Kuder Richardson 20. This method makes use of psychometric data obtained from one test administration [12]. It is assumed that items in the instrument are homogeneous and so possess inter-item consistency. An instrument is reliable when it could produce consistently each time numerical results [12]; [38]. The Kuder Richardson 20 was computed to determine the internal consistency and reliability of each item and the value was 0.78. The instrument was given to experts in tests and measurement, and lecturers in Mathematics Education who offered suggestions, and corrections were effected to improve the instrument.

\section{Data Analysis}

Inferential statistics of Pearson Product Moment Correlation (PPMC) was employed to test the hypothesis raised in this paper, as it measures relationships between the independent variable (instructional materials) on the only dependent variable (Mathematics performance)

\section{Result and Discussion}

Ho1: There is a significant relationship between availability and utilization of instructional materials on Grade 6 learners Mathematics performance.

Table 1 shows that there is a significant relationship between availability and utilization of instructional materials on Grade 6 learners Mathematics performance ( $\mathrm{r}$ $=0.999 ; \mathrm{p}>0.05)$.

Hypothesis: There is no significant relationship between instructional materials and Grade 6 learners' Mathematics performance. The findings revealed that the availability and utilization of instructional materials merged as predictors of Mathematics performance for Grade 6 students, and the hypothesis is therefore rejected.

Table 1. The Pearson Product Moment Correlation Summary of Relationship between availability and utilization of instructional materials on learners' Mathematics Performance

\begin{tabular}{|cccccc|}
\hline Variables & N & Mean & Standard Deviation & r & Sig \\
\hline $\begin{array}{c}\text { Availability and } \\
\text { Utilization of Instructional } \\
\text { Materials }\end{array}$ & & 51.002 & 15.827 & & \\
\\
Maths Performance
\end{tabular}


The above finding is corroborated by [37], who states that the use of instructional materials at the primary level has become an accepted fact the world over since the use of instructional materials in teaching and learning will enable the learner to develop manipulative skills, positive attitude, and problem-solving skills, acquire and develop functional knowledge. [12], affirms this notion when asserting that those learning institutions with abundant learning and teaching resources coupled with favourable student-teacher ratios, perform better than the institutions that do not provide the same. Access to instructional materials provides learners with concrete experiences and opportunities for experimenting and active implementation (doing), which is in line with Kolb's Experiential learning theory.

Ho2: There is no significant difference between male and female Grade Six learners' performance in Mathematics

Table 2 shows that there is no significant difference between male and female Grade 6 Mathematics performance at Buffalo City $(\mathrm{t}=-.217, \mathrm{df}=1218, \mathrm{p}>0.05)$ The mean difference between male learners $(\overline{\mathrm{x}}=12.820$, $\mathrm{SD}=3.969)$ and female learners $(\overline{\mathrm{x}}=12.872, \mathrm{SD}=4.098)$ was negligible. Therefore, hypothesis two is not rejected.

The finding of this study agrees with the findings of [8] that revealed an insignificant effect of gender on Mathematics performance. It is however in contrast with the findings of [2] and [3] which, discovered that they considered male understudies more capable in Mathematics than females Overall, it is trusted that if the two genders are given appropriate direction, openings, and adequate preparation, gender will not, at this point be an issue in Mathematics accomplishment when all is said in done.

\section{Conclusions}

The study explored the relationship between instructional materials and Grade 6 Mathematics performance. Authors use different definitions to describe instructional materials, however, all these authors acknowledge the predominant important role of instructional materials concerning the teaching of Mathematics. The use of varied instructional materials, comprising textbooks, charts; pictures, visual materials as well as concrete or physical objects, could do much to arouse learners' interest and develop their mathematical proficiency during the teaching-learning process. Whilst the use of instructional materials is essential for the development of learners' mathematical proficiency, the lack thereof could lead to poor academic achievements in Mathematics. Findings in the study also show that gender has no significant effect on learners' performance. However, the female students have the highest mean score than their male counterparts. It is recommended that teachers should not only be encouraged on the use of instructional materials, but also trained and guided on the effective use, management, improvisation, and selection of relevant and appropriate materials. The challenge is thus not only to encourage the effective use of instructional materials in South African schools but also to eliminate challenges responsible for the lack thereof in schools and factors that hinder the effective use, selection, and management of instructional materials.

\section{Data Availability}

The data collection instruments used in the current research are available from the corresponding author on request.

Table 2. Output of T-test on differences between Male and Female performance in Grade 6 mathematical concepts

\begin{tabular}{|c|c|c|c|c|c|c|c|c|}
\hline & Gender & $\mathrm{N}$ & Mean & Std Deviation & $\mathrm{T}$ & $\mathrm{Df}$ & $\operatorname{Sig}(\mathrm{P})$ & Remarks \\
\hline \multirow{2}{*}{$\begin{array}{c}\text { Mathematics } \\
\text { Performance }\end{array}$} & Male & 455 & 12.8198 & 3.96883 & -.217 & 1218 & .061 & Not Sig. \\
\cline { 2 - 9 } & Female & 765 & 12.8719 & 4.09818 & & & & \\
\hline
\end{tabular}




\section{REFERENCES}

[1] Abdullahi, A Mathematical knowledge for teaching fraction multiplication. 65 Cognition and Instruction, 26(1), 95-143, 2014.

[2] Abubakar, R.B Qualitative and functional mathematics education, does age and gender affect academic performance? Proceedings of 47th Annual National Conference of Mathematics Association of Nigeria (MAN) held at Nasarawa State Polytechnic, Lafia, Nigeria, 28th August - 3rd September 2010 pp 210- 215, 2010.

[3] Abubakar R. B., Oguguo O. D. Age, and gender as predictors of academic achievement of college mathematics and science students. Proceedings of the 2011 instructional conference on teaching, learning, and change. Institution association for teaching and learning (IATEL), 2011.

[4] Adu, K., O. The use of textbooks by teachers in teaching mathematics at selected primary schools in East London Education District. An unpublished dissertation submitted to faculty of education, University of Fort Hare. South Africa, 2018.

[5] Adu, K., O. Duku, N., S. Adu, E., O. Educators' perception on the importance of utilizing teaching resources in Grade 9 Mathematics. International Journal of Education Sciences. (IJES). 16(1, 3): 7-13, 2016.

[6] Adom, G., Adu, E., O. Motivation and attitude of grade nine learners towards Mathematics in King Williams Town Education District. Ghana Journal of Development Studies. (GJDS), 15(1): 133-148, 2018.

[7] Agina-Obu, T. N. The relevance of instructional materials in teaching and learning. Theories and practice of teaching, Port Harcourt: Harvey Publication. 2005.

[8] Ahmad, N.A., Jelas, Z.M. Ali, M.M. The relationship between learning styles and strategies with academic achievement based on gender and type of school. The International Journal of Learning, 17(10): 265-278. 2011.

[9] Akinoso, S.O. Effects of concrete representational-abstract and explicit instructional strategies on senior secondary school students' achievement in and attitude to Mathematics. Unpublished Ph.D. Thesis University of Ibadan, Ibadan, 2012.

[10] Australian Government. The school of the air and remote learning. Retrieved from http://www.australia.gov.au/about -australia/australian-story/school-of-theair , 2016.

[11] Azuka, B. F. Assessment in primary school Mathematics classrooms in Nigeria. International Journal of Education Learning and Development, 2 (2): 50-58, 2014.

[12] Babbie, L. Do ten-year-old children in Sweden know how they learn? A study of how students believe they learn compared to their learning style preferences. International Education Studies, 5(6):11-23, 2012.

[13] Baranyai, G. Stark, O. Effects of learning styles-based instruction on academic achievement, retention level, and attitudes towards English course. Journal of Faculty of Educational Sciences, 46(2):133-158, 2011.
[14] Brudett, M. Smith, R. Leadership in Education London: Sage Publishers. 2014.

[15] Drews, D. Do resources matter in primary mathematics? Using resources to support mathematical thinking, primary and early years. Exeter: Learning Matters, 2017.

[16] Ekpe, C. Estudio de las interacciones en el aula desde una perspectiva de género. Unpublished Master's Thesis, Department of Mathematics Education, Cinvestav-IPN, México, 2010.

[17] Esu, B., Enukoha, R. Umoren, D. Student error patterns as a function of curriculum design. Teaching Fractions to Remedial High School Students with Learning Disability. $A$ Journal of Learning Disability 23-29. Boston: Pearson, 2010.

[18] Ibe-Bassey, G.S. How Nigerian teachers select instructional materials for instruction. British Journal of Educational Technology, 2-3, 2008.

[19] Ikwuas, O.A, Onwiodiket, Y. Mathematics phobia, diagnosis and prescription. First Annual Lecture: National Mathematics Centre, Abuja. 2013.

[20] Iyunade, O.T. Availability, and utilization of instructional materials in selected andragogic setting in Ogun State, Nigeria. International Journal of Humanities and Social Science. 4(4): 268-273, 2014.

[21] Kolawole, A. Practical use of ICT in science and mathematics teachers' training at DUCE (Master's thesis, University of Twente, The Netherland). Retrieved from http://www.grin.com/en/e-book/179521/practical-use-of-ict -inscience-and-Mathematics-teachers-training-at-duce, 2010.

[22] Kolb, D. A. Kolb, A. Experiential learning: Experience as the source of learning and development (Vol. 1). Englewood Cliffs, NJ: Prentice-Hall, 2005.

[23] Lipik, M. Analyzing the use of textbooks in Mathematics education: The case of Estonia. ACTA PAEDAGOGICA VILNENSIA 35, 2005.

[24] Mba, T. N. Adult education and development. Port Harcourt: Pearl Publisher, 2014.

[25] Meremikwu, A.N. Instructional Aids, Gender, and Primary School Learners Achievement on Retention in Mathematics. In Cross River State, Nigeria. Unpublished Ph.D. Thesis, University of Calabar. Nigeria, 2008.

[26] Mntunjani, L. The use of mathematical resources to teach number concepts in the foundation phase. An unpublished dissertation submitted to faculty of education, Cape Peninsula University of Technology. South Africa, 2016.

[27] Mullis, I.V.S., Martin, M. O., Foy, P., Arora, A. TIMSS 2011 international results in Mathematics. Chestnut Hill, MA: TIMSS \& PIRLS International Study Center, Boston College, 2012.

[28] Munchi, N.T. Using the Videotape Instruction Technique in Teaching "Saving your Energy" Science Teachers Association of Nigeria integrated science education series no 6 (36), 2008.

[29] Nwichi, B. Teacher remuneration, and productivity in Nigerian secondary schools. New York: Hill Int, 2012. 
[30] Nzesei, M.M. A correlation study between learning styles and academic achievement among secondary school students in Kenya. M.Ed. dissertation submitted to the Department of Psychology. University of Nairobi. 2015.

[31] Obara, J. K. The efficacy of instructional media materials' utilization: Its implication to teaching. Nigerian Journal of empirical studies in psychology and Education. 1, (16) $16-$ 22, 2012.

[32] Ogundiran, S.O. Instructional materials' availability, and utilization: implications on public primary school students' academic performance in the Ibarapa North local government area of Oyo state. Journal of Educational Review. 8(1)71-80, 2015.

[33] Okeke, E. C. Instructional materials for environmental adult education: challenges for curriculum development in Nigeria. Nigerian journal of curriculum studies. 12, (1) 288 $-291,2015$.

[34] Opara, M. The use of instructional materials in primary schools. Three days be on the full implementation of university basic education in Imo State. 2012.

[35] Orji, E.I. Effect of cognitive conflict instructional model on students' conceptual change and attention in temperature and heat (Unpublished M.Ed. thesis). The University of Nigeria, 2012.

[36] Orhun, E. N. Need for using instructional materials in junior secondary schools in Afikpo North. Unpublished NCE Project Ebonyi State College of Education IKWO, 2013

[37] Sanni, S. Learning styles of prospective teachers: Kocaeli University case. Journal of Educational and Instructional Studies in the world, 3(2):1-12, 2011.
[38] Savoury, J. E. Class organization and administration. London: Nicholas and Coy Ltd. 2014.

[39] Setati, M. When language is transparent: supporting Mathematics learning multilingual contexts page 235 - 241. AMES a Congress 2009 proceedings, 2011.

[40] SMASE, Smasse Training Program. Unpublished Raw Data. 2010.

[41] Wales, F. Alternate funding of education. New York: Free Press. 2011

[42] Stein, M. K. Kim, G. The role of Mathematics curriculum materials in large-scale urban reform. In J. T. Remillard, B. A. Herbel-Eisenmann, \& G. M. Lloyd (Eds.), Mathematics teachers at work: Connecting curriculum materials and classroom instruction (pp.37-55). New York: Routledge, 2016.

[43] Tatag, Y.S., Sugi, H. Ahmad W.K. Karim, Kurniawan. Instrumentalist Teachers' Beliefs in Practicing Mathematical Problem Solving. Universal Journal of Educational Research 7(12): 2851-2856, 2019

[44] Thomson, S., Wernert, N., Underwood, C., Nicholas, M. TIMSS 2007: Taking a closer look at Mathematics and science in Australia. Camberwell: Australian Council for Educational Research, 2011.

[45] TIMSS. International results in mathematics executive summary. Boston: Boston College, 2011.

[46] UNESCO Challenges of Implementing Free Day Secondary Schools in Kenya. Experiences from District, Nairobi: UNESCO, 2006. 